\title{
High Density Poly Ethylene Nylon Netting in Runner Beans (Phaseolus vulgaris) Improve the Quality \& Quantity of Fruits under Rain Fed up Land Farming Situation
}

\author{
Dr. Sidhartha Kar \\ Scientist Agriculture - Horticulture, KVK, Kandhamal, Odisha, India \\ E mail: sidharthakar7@ gmail.com, cell: +919437633251
}

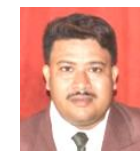

Abstract - Agriculture plays a vital role of our national economy. Most of our culture traditions are linked with crop production. However concentration of farming communities decreasing Day by Day due to hardiness in crop management and post planting operation in crop field such as application of nutrients, plant protection majors, quality fruit production related operations \& harvesting mechanisms etc. As far as runner vegetables cultivation is concern by traditional staking $\&$ less space in between the rows for movement $\&$ management and vertical runner vegetable farming with infectious and damage crop production decreases the efficiency of farm families. It was also observed that, due to limited space between plant to plant $\&$ row to row planting and staking by fire wood in runner vegetables or by farming without stalk, agriculture inputs cost such as plant protection equipment, irrigation, fertiliser, agricultural labourer competence \& quantity of human Days for post planting operations, production of injurious fruits \& vegetables increase. High agriculture input cost and low productivity of quality fruits \& vegetables decreases benefit cost ratio (B:C ratio) \& market demand which ultimately fails to meet expectations of consumer or purchaser about quality runner vegetables in concern to appearance, taste \& presence of essential nutrients such as calorie 26c, carbohydrate $4.5 \mathrm{gm}$, protein $1.7 \mathrm{gm}$, fats $0.1 \mathrm{gm}$ \& Vitamin A $132 \mathrm{mg}$, Vitamin B 0.14 $\mathrm{mg}$, Vitamin C $24 \mathrm{mg}$, lime 50mg \& Iron $1.7 \mathrm{mg}$ (out of 100 gram fresh bean vegetables). Observance the problems in intelligence this experiment on "High Density Poly Ethylene Nylon Netting in Runner beans improves the quality \& quantity of fruits under rain fed up land farming situation" has been carried out in hill zone of our State Odisha. Kandhamal is a District situated in Eastern Ghats agro climatic zone of the State Odisha, India.

This Experiment was laid out in Randomized Block Design (RBD) with six treatments (T) \& five replications (R) at Kandhamal District of Odisha, India during the Year 2019-20 under the direction of Horticulture Scientist of Krishi Vigyan Kendra, Kandhamal at G. Udayagiri. The farming situation of the experimental site is rain fed up land situation and experiment was started during the month of June. The soil type of experimental site is laterite with rich source of organic matter due to presence of forest leaf bio mass with appreciable soil pH 6.5 and macro such as NPK nutrients is medium in nature. The agro ecological situation consists a rain fall from range of $\mathbf{1 1 0 0}$ - $1300 \mathrm{~mm} \&$ moderate in nature. The experiment was carried by adopting only organic nutrition to plant by using farm yard manure, vermi compost, bio logically prepared N, P2O5 \& K2O. Plant protection materials such as Trichoderma @ 4ml./litre of water, Neem oil @ 5ml./ litre of water is used for crop management. The geographical elevation of the experimental site is $20^{\circ} 08$, 20.5" North \& $84^{\circ} 20^{\prime} 34.7^{\prime \prime}$ in East direction. Treatment such as T0 - Horizontal spread above the soil of $R$. Bean plant with broadcasting of seeds, $\mathrm{T} 1$ - Staking with fire wood in a spacing $0.5 \mathrm{~m}$ in line $\& 0.5 \mathrm{~m}$ in rows, T2 - SLTS by HDPE Nylon net with bamboo stump spacing $1.5 \mathrm{~m}$ in line \& $1 \mathrm{~m}$ between rows, T3 - SLTS by HDPE Nylon net with bamboo stump spacing $1.5 \mathrm{~m}$ in line $\& 0.6 \mathrm{~m}$ between rows, T4 - SLTS by HDPE Nylon net with bamboo stump spacing $2 \mathrm{~m}$ in line \& $1 \mathrm{~m}$ between rows \& T5 - SLTS by HDPE Nylon net with bamboo stump spacing $2 \mathrm{~m}$ in line \& $0.6 \mathrm{~m}$ between rows has been taken with five replications. As far as yield of different treatment is concern $\mathrm{T} 3$ that is SLTS by HDPE Nylon net with bamboo stump spacing $1.5 \mathrm{~m}$ in line $\& \mathbf{0 . 6 m}$ between rows has maximum yield with 165 quintal per hectare \& by netting technology all most all treatments Yellow Vain Mosaic Virus (YVMV) was found resistant in comparison to vertical above the soil traditional farming $\&$ runner bean farming by fire wood stalking which is set up susceptible.

Performance indicators such as gross cost, gross return, net return, $\mathrm{BC}$ ratio \& \% increase in income of the experiment analyse by actual figures collected from grass root label institutions such as farmer's field, market analysis. All six treatments data collected and mathematical analysis carried out and set up SLTS by HDPE Nylon net with bamboo stump spacing $1.5 \mathrm{~m}$ in line \& $0.6 \mathrm{~m}$ between rows has highest economical returns and 
ISSN (online): 2581-3048

a net profit of $\mathrm{Rs} .98,000 /-$ per hectare with a $\mathrm{B}$ :C ratio of 1.98.

It is concluded that High Density Poly Ethylene Nylon Netting in Runner beans improve the quality \& quantity of fruits and responses found utmost by treatment SLTS by HDPE Nylon net with bamboo stump spacing $1.5 \mathrm{~m}$ in line \& $0.6 \mathrm{~m}$ between rows in concern to yield \& economic parameter. Apart from that disease such as YVMV is very lesser \% by nylon netting. Single Line Trellis System (SLTS) system by using HDPE Nylon Net reduces the stresses due to traditional stalking, crop management become smooth. Production increases, incidence of YVMV disease decrease and farm family income increases due to fetching better market price. Yield and plucking of fruits are appreciable and beneficiary want to multiply in massive scale. It is plan to conduct demonstration in all runner vegetable to doubling the farmer's income from vegetable garden.

Keywords: Netting management, vegetable mechanise farming, Runner beans farming, SLTS in beans.

\section{INTRODUCTION}

Agriculture plays a vital role of our national economy. Most of our culture traditions are linked with crop production. However concentration of farming communities decreasing Day by Day due to hardiness in crop management and post planting operation in crop field such as application of nutrients, plant protection majors, quality fruit production related operations \& harvesting mechanisms etc. As far as runner vegetables cultivation is concern by traditional staking $\&$ less space in between the rows for movement \& management and vertical runner vegetable farming with infectious and damage crop production decreases the efficiency of farm families. It was also observed that, due to limited space between plant to plant \& row to row planting and staking by fire wood in runner vegetables or by farming without stalk, agriculture inputs cost such as plant protection equipment, irrigation, fertilizer, agricultural laborer competence \& quantity of human Days for post planting operations, production of injurious fruits \& vegetables increase. High agriculture input cost and low productivity of quality fruits \& vegetables, decreases benefit cost ratio (B:C ratio) \& market demand which ultimately fails to meet expectations of consumer or purchaser about quality runner vegetables in concern to appearance $\&$ taste.

Observance the problems in intelligence this experiment on "High Density Poly Ethylene Nylon Netting in Runner beans improves the quality \& quantity of fruits under rain fed up land farming situation" has been carried out in hill zone of our State. Kandhamal is a District situated in Eastern Ghats agro climatic zone of the State Odisha, India. This district is situated in 300 meters to 1100 meters Mean Sea Label and covers with hills \& mountain. The major source of income of tribal families is agriculture, collection of non timber forest products \& its marketing in local regulated market. In their crop pattern they are doing turmeric, potato, runner beans, brinjal \& other leafy vegetables. Out of all vegetables runner beans farming play an important role of tribal family livelihood and they have adopted this crop since last 70 Years with a present coverage around 500 hectare in the District. Due to its tenderness, organically grown beans fruit taste, presence essential nutrients \& vitamin such as calorie 26c, carbohydrate $4.5 \mathrm{gm}$, protein $1.7 \mathrm{gm}$, fats $0.1 \mathrm{gm} \&$ Vitamin A $132 \mathrm{mg}$, Vitamin B $0.14 \mathrm{mg}$, Vitamin C $24 \mathrm{mg}$, lime 50mg \& Iron $1.7 \mathrm{mg}$ (out of 100 gram fresh bean vegetables) its demand is all over the State. Beans plants are climbing in nature and required support to grow and fruiting. Before experiment farmers are doing beans farming by vertical spread of plant above the ground which results smaller fruits and infected by insect-pests \& diseases. After few Years of farming they have adopted horizontal staking technology with ridge $\&$ furrow methods which are also continuing in most of the farmer's field till date. Stalking with fire wood able to meet the production barrier somehow, but vegetative growth, fruit size, yield, productivity \& crop management in side beans field became cumbersome and also collection of stalking materials are hard and labour intensive due to unsustainable in nature. Keeping these views in mind Krishi Vigyan Kendra, Kandhamal at G. Udayagiri started to demonstrate trellis with HDPE Nylon poly net management in runner beans variety Raikia Beans during the Year 2019-20 in farmer's field under the guidance of Horticulture Scientist. The main objective of this experiment is to demonstrate the single line trellis management in runner beans with different spacing assessment and aware about the benefits to tribal farmer such as vertical garden, sustainable trellis materials (HDPE nylon net with bamboo or iron angle stalking) which can be use for more than ten years, easy to move inside the beans field for crop management and harvesting, quality harvest of beans size fruits and multiple use of net in off season such as fencing, covering of crops from avian damage etc.

\section{MATERIALS \& METHODS}

Experiment on "High Density Poly Ethylene Nylon Netting in Runner beans improve the quality \& quantity of fruits under rain fed up land farming situation" was laid out in Randomized Block Design (RBD) with six treatments (T) \& five replications $(\mathrm{R})$ at Kandhamal District of Odisha, India during the Year 2019-20 under the direction of Horticulture Scientist of Krishi Vigyan Kendra, Kandhamal at G. Udayagiri. The farming situation of the experimental site is 
ISSN (online): 2581-3048

rain fed up land situation and experiment was started during the month of June. The soil type of experimental site is laterite with rich source of organic matter due to presence of forest leaf bio mass with appreciable soil $\mathrm{pH} 6.5$ and macro such as NPK nutrients is medium in nature. The agro ecological situation consists a rain fall from range of $1100-1300 \mathrm{~mm} \&$ moderate in nature. The experiment was carried by adopting only organic nutrition to plant by using farm yard manure, vermi compost, bio logically prepared N, P2O5 \& K2O. Plant protection materials such as Trichoderma @ 4ml./litre of water, Neem oil @ 5ml. / litre of water is used for crop management. The geographical elevation of the experimental site is $20^{\circ} 08^{\prime} 20.5^{\prime \prime}$ North \& $84^{\circ} 20^{\prime} 34.7^{\prime \prime}$ in East direction. Treatment such as T0 - Horizontal spread above the soil of Runner Bean plant with broadcasting of seeds, T1 - Staking with fire wood in a spacing $0.5 \mathrm{~m}$ in line $\& 0.5 \mathrm{~m}$ in rows, T2 SLTS by HDPE Nylon net with bamboo stump spacing $1.5 \mathrm{~m}$ in line \& $1 \mathrm{~m}$ between rows, T3 - SLTS by HDPE Nylon net with bamboo stump spacing $1.5 \mathrm{~m}$ in line $\& 0.6 \mathrm{~m}$ between rows, T4 - SLTS by HDPE Nylon net with bamboo stump spacing $2 \mathrm{~m}$ in line $\& 1 \mathrm{~m}$ between rows \& T5 - SLTS by HDPE Nylon net with bamboo stump spacing $2 \mathrm{~m}$ in line \& $0.6 \mathrm{~m}$ between rows has been taken with five replications.

\section{RESULTS}

Yield Parameter: As far as yield of different treatment is concern T 3 that is SLTS by HDPE Nylon net with bamboo stump spacing $1.5 \mathrm{~m}$ in line \& $0.6 \mathrm{~m}$ between rows has maximum yield with 165 quintal per hectare followed by $\mathrm{T} 2$, T 5, T 4, T 1 \& T0. Similarly other parameter such as Average length of bean fruits in $\mathbf{~} \mathbf{T} \mathbf{4}$ has found highest length of beans fruit that is $21.4 \mathrm{~cm}$. followed by T 5, T 3, T 2, T 1 \& $\mathrm{T} 0$ and in parameter Average weight of single bean fruits in gm. $\mathbf{T} 4$ has maximum single fruit weight that is $\mathbf{2 3 . 4}$ gm. Follower by T 2, T 3, T 1, T 5 \& $\mathbf{T} 0$ respectively. Statistical analysis reflects that there is a significant difference in yield by High Density Poly Ethylene Nylon Netting in Runner beans with different spacing and control treatments. Table 1 describes details about the results of all treatments.

Table 1: Details about the results of all treatments

\begin{tabular}{|c|c|c|c|c|}
\hline Treatment & $\begin{array}{l}\text { Details of technology carried out } \\
\text { under experiment on runner beans }\end{array}$ & $\begin{array}{l}\text { Average } \\
\text { length of } \\
\text { bean } \\
\text { fruits in } \\
\mathrm{cm} .\end{array}$ & $\begin{array}{l}\text { Average } \\
\text { weight } \\
\text { of } \\
\text { single } \\
\text { bean } \\
\text { fruits in } \\
\text { gm. }\end{array}$ & $\begin{array}{c}\text { Average } \\
\text { Yield } \\
\text { per } \\
\text { hectare } \\
\text { (quintal) }\end{array}$ \\
\hline $\begin{array}{c}\text { T0 } \\
\text { (Control) }\end{array}$ & $\begin{array}{l}\text { Horizontal spread above the soil of } R \text {. } \\
\text { Bean plant with broadcasting of } \\
\text { seeds. }\end{array}$ & 14.2 & 15.6 & 85 \\
\hline T1 & $\begin{array}{l}\text { Staking with fire wood in a spacing } \\
0.5 \mathrm{~m} \text { in line \& } 0.5 \mathrm{~m} \text { in rows. }\end{array}$ & 18.8 & 20.45 & 128 \\
\hline $\mathrm{T2}$ & $\begin{array}{l}\text { SLTS by HDPE Nylon net with } \\
\text { bamboo stump spacing } 1.5 \mathrm{~m} \text { in line \& } \\
1 \mathrm{~m} \text { between rows. }\end{array}$ & 19.2 & 22.8 & 142 \\
\hline T3 & $\begin{array}{l}\text { SLTS by HDPE Nylon net with } \\
\text { bamboo stump spacing } 1.5 \mathrm{~m} \text { in line \& } \\
0.6 \mathrm{~m} \text { between rows. }\end{array}$ & 19.4 & 22.5 & 165 \\
\hline T4 & $\begin{array}{l}\text { SLTS by HDPE Nylon net with } \\
\text { bamboo stump spacing } 2 \mathrm{~m} \text { in line \& } \\
1 \mathrm{~m} \text { between rows. }\end{array}$ & 21.4 & 23.4 & 134 \\
\hline T5 & $\begin{array}{l}\text { SLTS by HDPE Nylon net with } \\
\text { bamboo stump spacing } 2 \mathrm{~m} \text { in line \& } \\
0.6 \mathrm{~m} \text { between rows. }\end{array}$ & 19.5 & 22.2 & 138 \\
\hline & Total & 112.5 & 126.95 & 792 \\
\hline & Average & 22.5 & 25.39 & 158.4 \\
\hline \multicolumn{4}{|c|}{ SEM } & 2.9 \\
\hline \multicolumn{4}{|c|}{$\mathrm{CD}(0.05)$} & 6.05 \\
\hline
\end{tabular}

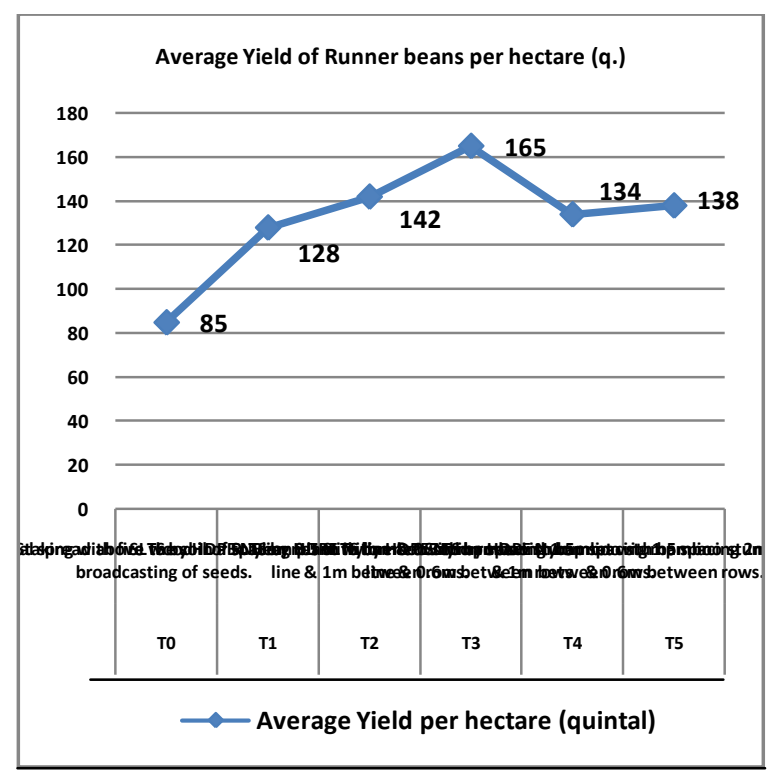

Incidence of Yellow Vain Mosaic Virus: In experiment analysis of incidence of insects - pests \& Diseases specially Yellow Vain Mosaic Virus (YVMV) done by random sampling and score card method and it was set up T 2, T 3, T 4, T 5 are resistant to YVMV, where as among all treatment $\mathrm{T} 0$ found highly susceptible to YVMV and T 1 is susceptible to YVMV.

Table number -2 reflects in details about the incidence $\%$ and score card analysis. 
Table 2: Details about the incidence \% and score card analysis

\begin{tabular}{|c|l|c|c|}
\hline Treatment & Details of technology & $\begin{array}{l}\text { YVMV } \\
\text { incidence \% }\end{array}$ & $\begin{array}{l}\text { Reaction to } \\
\text { treatment }\end{array}$ \\
\hline $\begin{array}{c}\text { T0 } \\
\text { (Control) }\end{array}$ & $\begin{array}{l}\text { Horizontal spread above the } \\
\text { soil of R. Bean plant with } \\
\text { broadcasting of seeds. }\end{array}$ & 25 & $\begin{array}{c}\text { Highly } \\
\text { Susceptible }\end{array}$ \\
\hline T1 & $\begin{array}{l}\text { Staking with fire wood in a } \\
\text { spacing 0.5 } \mathrm{m} \text { in line \& 0.5m } \\
\text { in rows. }\end{array}$ & 15 & Susceptible \\
\hline T2 & $\begin{array}{l}\text { SLTS by HDPE Nylon net with } \\
\text { bamboo stump spacing 1.5m } \\
\text { in line \& 1m between rows. }\end{array}$ & 3 & Resistant \\
\hline T3 & $\begin{array}{l}\text { SLTS by HDPE Nylon net } \\
\text { with bamboo stump } \\
\text { spacing 1.5m in line \& } \\
\text { 0.6m between rows. }\end{array}$ & 4 & Resistant \\
\hline T4 & $\begin{array}{l}\text { SLTS by HDPE Nylon net with } \\
\text { bamboo stump spacing 2m } \\
\text { in line \& 1m between rows. }\end{array}$ & 2 & Resistant \\
\hline T5 & $\begin{array}{l}\text { SLTS by HDPE Nylon net with } \\
\text { bamboo stump spacing } 2 \mathrm{~m} \\
\text { in line \& 0.6m between } \\
\text { rows. }\end{array}$ & 3 & Resistant \\
\hline Below $5 \%$ is resistant, 5-20\% is susceptible \& 21 - 30\% is Highly susceptible \\
\hline
\end{tabular}

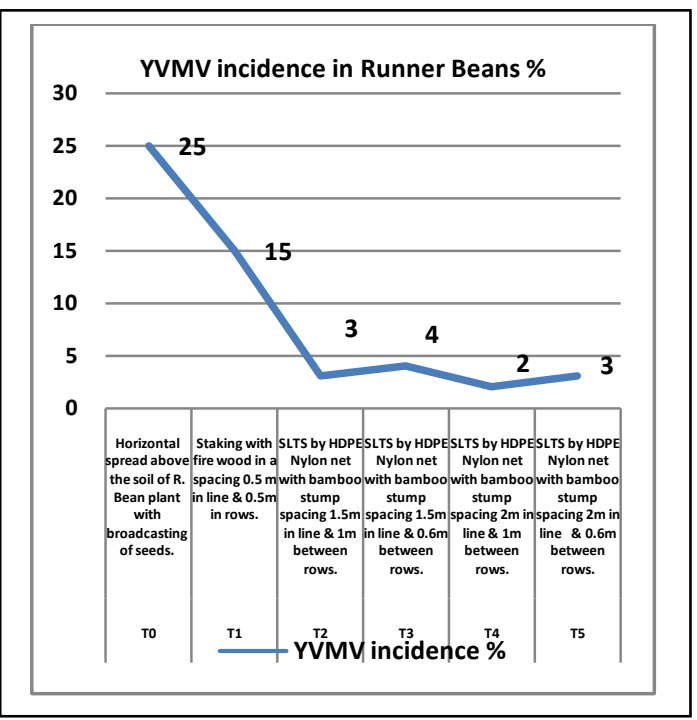

Economics Parameters: Performance indicators of the experiment analyze by actual figures collected from grass root label institutions such as farmer's field, market analysis. All six treatments data collected and mathematical analysis carried out as given in table number - 3. It was set up T 3 that is SLTS by HDPE Nylon net with bamboo stump spacing $1.5 \mathrm{~m}$ in line \& $0.6 \mathrm{~m}$ between rows has highest economical returns and a net profit of Rs. 98,000/- per hectare with a B:C ratio of 1.98 followed by $T$ 2, T 4, T5, T $1 \&$ T 0 . Market rate of beans is depends up on the quality of fruits and by adopting the nylon netting and spacing technology quality of runner bean fruits is better and fetching good market rate.

Table 3: Six treatments data collected and mathematical analysis

\begin{tabular}{|c|c|c|c|c|c|c|c|}
\hline Treatment & Details of technology & $\begin{array}{l}\text { Gross Cost (GC) of } \\
\text { cultivation in Rs/ } \\
\text { hectare }\end{array}$ & $\begin{array}{l}\text { Gross return (GR) of } \\
\text { cultivation in Rs/ } \\
\text { hectare }\end{array}$ & $\begin{array}{l}\text { Gross return (NR) of } \\
\text { cultivation in Rs/ } \\
\text { hectare }\end{array}$ & $\begin{array}{l}\mathrm{B}: \mathrm{C} \\
\text { ratio }\end{array}$ & $\begin{array}{ll}\% & \text { of } \\
\text { increase } & \text { in } \\
\text { income } & \end{array}$ & $\begin{array}{l}\text { Sailing rate } \\
\text { of R. Beans } \\
\text { Rs./q. }\end{array}$ \\
\hline $\begin{array}{c}\text { T0 } \\
\text { (Control) }\end{array}$ & $\begin{array}{l}\text { Horizontal spread above the soil } \\
\text { of R. Bean plant with } \\
\text { broadcasting of seeds. }\end{array}$ & 45000 & 68000 & 23000 & 1.51 & 51.11 & 800 \\
\hline T1 & $\begin{array}{l}\text { Staking with fire wood in a } \\
\text { spacing } 0.5 \mathrm{~m} \text { in line } \& 0.5 \mathrm{~m} \text { in } \\
\text { rows. }\end{array}$ & 75000 & 128000 & 53000 & 1.71 & 70.67 & 1000 \\
\hline $\mathrm{T2}$ & $\begin{array}{l}\text { SLTS by HDPE Nylon net with } \\
\text { bamboo stump spacing } 1.5 \mathrm{~m} \text { in } \\
\text { line } \& 1 \mathrm{~m} \text { between rows. }\end{array}$ & 90000 & 170400 & 80400 & 1.89 & 89.33 & 1200 \\
\hline T3 & $\begin{array}{l}\text { SLTS by HDPE Nylon net with } \\
\text { bamboo stump spacing } 1.5 \mathrm{~m} \text { in } \\
\text { line } \& 0.6 \mathrm{~m} \text { between rows. }\end{array}$ & 100000 & 198000 & 98000 & 1.98 & 98.00 & 1200 \\
\hline T4 & $\begin{array}{l}\text { SLTS by HDPE Nylon net with } \\
\text { bamboo stump spacing } 2 \mathrm{~m} \text { in } \\
\text { line } \& 1 \mathrm{~m} \text { between rows. }\end{array}$ & 85000 & 160800 & 75800 & 1.89 & 89.18 & 1200 \\
\hline T5 & $\begin{array}{l}\text { SLTS by HDPE Nylon net with } \\
\text { bamboo stump spacing } 2 \mathrm{~m} \text { in } \\
\text { line } \& 0.6 \mathrm{~m} \text { between rows. }\end{array}$ & 95000 & 165600 & 70600 & 1.74 & 74.32 & 1200 \\
\hline
\end{tabular}

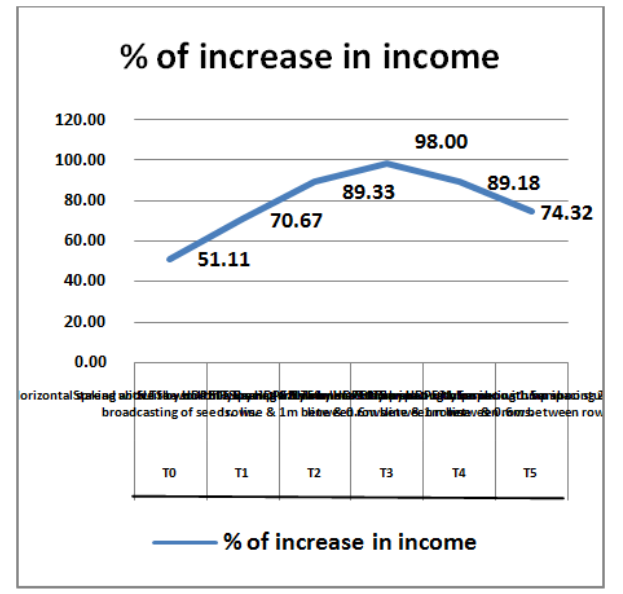


ISSN (online): 2581-3048

Volume 4, Issue 7, pp 35-39, July-2020

https://doi.org/10.47001/IRJIET/2020.407006

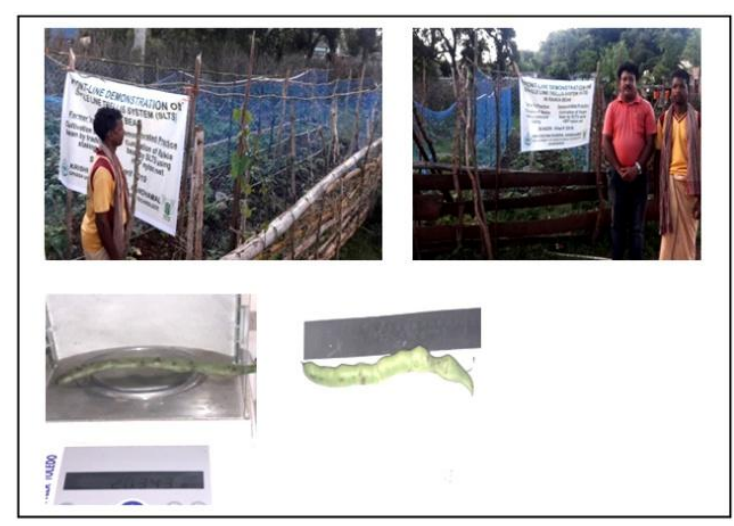

Figure 1: Percentage of increase in income

\section{CONCLUSION}

It is concluded that High Density Poly Ethylene Nylon Netting in Runner beans improve the quality \& quantity of fruits and responses found utmost by treatment SLTS by HDPE Nylon net with bamboo stump spacing $1.5 \mathrm{~m}$ in line \& $0.6 \mathrm{~m}$ between rows in concern to yield \& economic parameter. Apart from that disease such as YVMV is very lesser \% by nylon netting. Single Line Trellis System (SLTS) by using HDPE Nylon Net reduces the stresses due to traditional stalking, crop management become smooth. Production increases, incidence of YVMV disease decrease and farm family income increases due to fetching better market price. Yield and plucking of fruits are appreciable and beneficiary want to multiply in massive scale. It is plan to conduct demonstration in all runner vegetable to doubling the farmer's income from vegetable garden.

\section{REFERENCES}

[1] Indian Council for Agriculture Research.

[2] homeguides.sfgate.com/build-vegetable-trellis.

[3] performancefabrics.com

[4] Central Horticulture Experiment Station (CHES).

\section{Citation of this Article:}

Dr. Sidhartha Kar, "High Density Poly Ethylene Nylon Netting in Runner Beans (Phaseolus vulgaris) Improve the Quality \& Quantity of Fruits under Rain Fed up Land Farming Situation" Published in International Research Journal of Innovations in Engineering and Technology - IRJIET, Volume 4, Issue 7, pp 35-39, July 2020.

https://doi.org/10.47001/IRJIET/2020.407006 